\title{
Assessment of the bioavailability and toxicity of lead polluted soils using a combination of chemical approaches and bioassays with the collembolan Folsomia candida
}

\author{
Wei Luo $^{\mathrm{a}, \mathrm{b}}$, Rudo A. Verweij ${ }^{\mathrm{b}}$, Cornelis A.M. van Gestel ${ }^{\mathrm{b}, *}$ \\ a State Key Lab of Urban and Regional Ecology, Research Center for Eco-Environmental Sciences, Chinese Academy of Sciences, Beijing 100085, China \\ ${ }^{\mathrm{b}}$ Department of Ecological Science, Faculty of Earth and Life Sciences, VU University, De Boelelaan 1085, 1081 HV Amsterdam, The Netherlands
}

\section{H I G H L I G H T S}

- Soils from different landscapes of a shooting range are examined.

- Bioavailability of $\mathrm{Pb}$ varies with soil properties especially, $\mathrm{pH}$ and $\mathrm{OM}$.

- Collembolan reproduction was more sensitive to $\mathrm{pH}$ than to $\mathrm{Pb}$ in soils.

- Collembolans avoided acid Pb contaminated soils.

\section{A R T I C L E I N F O}

\section{Article history:}

Received 29 January 2014

Received in revised form 7 August 2014

Accepted 9 August 2014

Available online 2 September 2014

\section{Keywords:}

Springtails

Contaminated soils

Soil properties

Avoidance test

Bioaccumulation

\begin{abstract}
A B S T R A C T
Understanding bioavailability and toxicity is essential for effective ecological assessment of contaminated soils. Total, water and $0.01 \mathrm{M} \mathrm{CaCl}_{2}$ extractable and porewater $\mathrm{Pb}$ concentrations and soil properties in different shooting field soils were investigated. Three artificial soils containing different $\mathrm{pH}$ and organic matter contents and two natural soils were included as controls. Survival, reproduction and avoidance responses of Folsomia candida exposed to these soils as well as internal $\mathrm{Pb}$ concentrations were measured. In the shooting range soils, total $\mathrm{Pb}$ concentrations were $47-2398 \mathrm{mg} / \mathrm{kg} \mathrm{dw}, \mathrm{pH}_{\mathrm{CaCl}_{2}} 3.2-6.8$ and organic matter content $3.8-7.0 \%$. Pb concentrations in $\mathrm{F}$. candida linearly increased with increasing $\mathrm{Pb}$ concentrations in the soils. Acid forest soils caused significantly higher collembolan mortality and avoidance responses and significantly lower reproduction than the neutral grassland soils, which could be attributed to differences in $\mathrm{pH}$ and especially $\mathrm{CaCl}_{2}$ extractable $\mathrm{Pb}$ concentrations. Soil properties significantly affected bioavailability and toxicity of $\mathrm{Pb}$, but overall the collembolans seemed more sensitive to $\mathrm{pH}$ than to $\mathrm{Pb}$ in soils. This study shows the importance of selecting proper reference soils for assessing the effects of field soils.
\end{abstract}

(c) 2014 Elsevier B.V. All rights reserved.

\section{Introduction}

Lead-contaminated land is a global environmental problem that results not only in ecological and human health risks, but can also have large financial implications in terms of remediation costs and re-development issues [1]. Shooting ranges, used for both military training and sport, can constitute an important source of lead $(\mathrm{Pb})$ contamination in terrestrial ecosystems due to the use of ammunition pellets containing $\mathrm{Pb}[2]$. Because of its widespread use and its possible irreversible impairment of ecological soil processes,

\footnotetext{
* Corresponding author. Tel.: +31 205987079.

E-mail address: kees.van.gestel@vu.nl (C.A.M. van Gestel).
}

environmental risks associated with $\mathrm{Pb}$ contamination at shooting ranges are receiving increased interest from various national and international regulatory organizations [3].

$\mathrm{Pb}$ availability measured using extractants such as weak salts or weak acids may provide a first indication of the potential risk [4]. However, the uncertainty associated with the performance of extractants under various environmental conditions hinders endorsement of single or sequential extraction procedures. To address the relevance of chemical extraction methods for risk assessment, the analytically extracted metal concentrations need to be interpreted in a biological context [5]. There is an increasing need to incorporate bioassays in risk assessments and hazard identification [6,7]. Bioassays with soil animals however, may also present some problems: acute tests, for instance, do not provide an 
insight into the effects of the contaminant on population dynamics while chronic tests are time-consuming and labor intensive [8]. In acute toxicity tests, some soil invertebrate species proved to be very resilient, with an "avoidance mechanism" that distorted the results toward lower toxicity values than expected [9]. As an alternative to the classic survival or reproduction tests therefore sub-lethal avoidance behavior tests have been developed as ecologically relevant, sensitive, rapid, and cost-effective first screening tools for assessing soil contamination [9-11].

Since earthworms avoid $\mathrm{Pb}$ treated soil (1000-10,000 mg $\mathrm{Pb} / \mathrm{kg} \mathrm{dw}$ ) in a dose-related manner and prefer neutral to slightly acidic soils ( $\mathrm{pH}$ tolerance: 4.0-9.0), they may not be suitable for testing more acidic soils $[12,13]$. Soil dwelling collembolans are considered ecologically relevant species for ecotoxicological tests because they represent arthropods that have a different route of exposure and have a wider $\mathrm{pH}$ tolerance (3.2-7.7) compared to the earthworm species commonly used in toxicity tests [12,13]. The collembolan $F$. candida is often used as bioindicator for pollution due to its widespread distribution in different soil types, flexibility of its alimentary habits, its locomotor ability, and its role in the decomposition of organic matter, regulation of microbial activity and nutrient cycling $[10,14]$.

Terrestrial ecotoxicity not only varies between species but soil characteristics also greatly influence the effect of metals by altering bioavailability [15]. In previous studies, the effect of aging on the bioavailability of $\mathrm{Pb}$ was hardly taken into account. Because most toxicity tests were carried out in freshly spiked soils, the effect concentrations may be regarded as conservative [13]. When combined with environmental chemistry of naturally aged soils, bioassays (including avoidance tests) provide more complete and relevant information on contaminant bioavailability in soils and, therefore a more meaningful and holistic risk assessment of contaminated sites $[9,16]$. To considerably improve site-specific risk assessment of $\mathrm{Pb}$-contaminated land, it is highly recommended to combine soil characterization, chemical extraction methods and bioassays $[7,9,10]$.

This study is part of a broader investigation that aimed at assessing the ecotoxicological risk of $\mathrm{Pb}$ in shooting range soils and deals with the effects on springtails; earlier studies described the effects on earthworms and enchytraeids $[17,18]$. Six natural field soils were collected from different landscapes (bullet plot, forest and grass lands) of a shooting field in the Netherlands, representing a gradient of $\mathrm{Pb}$ pollution but also different $\mathrm{pH}$ and organic matter contents. To elucidate effects of main soil properties on collembolans, three artificial reference soils with different $\mathrm{pH}$ and organic matter contents were used for comparison. Relationships between the survival and reproduction of $F$. candida and the total and waterand $\mathrm{CaCl}_{2}$-extractable and porewater $\mathrm{Pb}$ concentrations in soil as well as internal $\mathrm{Pb}$ concentrations in the surviving collembolans were determined. In addition, the behavioral response of $F$. candida to $\mathrm{Pb}$ in the shooting field soils was also investigated. The final aim of this study was to combine conventional chemical analysis, longterm toxicity tests and short-term avoidance tests to support the environmental risk assessment of $\mathrm{Pb}$ in shooting field soils.

\section{Materials and methods}

\subsection{Soil sampling}

Six natural soils were sampled from forest $(F)$, grassland $(G)$ and bullet plot (B) fields, which represent three landscapes of a shooting field in the Netherlands. Assuming it had similar soil properties without being contaminated, a soccer field soil (S) near the shooting range was sampled as a reference for the survival and reproduction tests. Three artificial soils (R1, R2, R3) were prepared based on OECD artificial soil [19] in order to "mimick" the shooting field soils in $\mathrm{pH}$ and organic matter content, assuming these properties had more effect on $\mathrm{Pb}$ toxicity than soil texture. A standard artificial soil (R1) were prepared by mixing $10 \%$ finely ground sphagnum peat $(<1 \mathrm{~mm}), 20 \%$ kaolin clay, and $70 \%$ quartz sand (dry weight) and adjusting nominal $\mathrm{pH}_{\mathrm{CaCl}_{2}}$ to $6.0 \pm 0.5$ by adding $\mathrm{CaCO}_{3}$. The other two artificial soils were prepared by reducing peat contents to $5 \%$ (R2) or $2.5 \%$ (R3), increasing sand content accordingly and adjusting nominal $\mathrm{pH}_{\mathrm{CaCl}_{2}}$ to 3.5 (R2) or 6.5 (R3) with $\mathrm{CaCO}_{3}$. The standard natural LUFA 2.2 soil (LF2.2; LUFA-Speyer, Sp 2121 , Germany) was used as an additional control of the performance of the test animals.

For a full description of the methods used to analyze the soils, it can be referred to Luo et al. [17].

\subsection{Survival and reproduction toxicity tests}

Before starting the tests, all soils were dried completely at $50{ }^{\circ} \mathrm{C}$ and subsequently moistened to $50 \%$ of their water holding capacity (WHC). F. candida ("Berlin strain"; VU Amsterdam) were cultured in plastic containers with a moist bottom of plaster of Paris containing $10 \%$ charcoal, at $20^{\circ} \mathrm{C}$ at a light/dark regime of $12 / 12 \mathrm{~h}$. The experiment was initiated with 10-12 day old juveniles that were obtained by synchronizing the egg laying of the culture animals, fed with dried baker's yeast (Dr. Oetker). Tests with $F$. candida were carried out according to ISO guideline 11267 [20], using $100 \mathrm{ml}$ glass test containers containing $30 \mathrm{~g}$ moist soil each. Five replicates were prepared for each test, reference and control soil. At the start of the test, ten synchronized animals were transferred into each test jar and fed a few grains of dried baker's yeast. The jars were incubated in a climate room at $20 \pm 1{ }^{\circ} \mathrm{C}$ and at a light/dark regime of $12 / 12 \mathrm{~h}$. Once a week, the moisture content of the test soils was maintained by adding Milli-Q. After 28 days exposure, the content of each jar was flushed into a $300 \mathrm{ml}$ beaker glass using $100 \mathrm{ml}$ water. The mixture was gently stirred to let all surviving adults and juveniles produced floating on the water surface. A picture of the water surface was taken and the number of offspring was counted using digital imaging software.

Surviving adults were carefully taken from the water surface and allowed to remove excess water and empty their guts by placing them for a few minutes on a dry bottom of plaster Paris. After freeze-drying and determination of their dry weight, the animals were individually digested in a $300 \mu \mathrm{HClO}_{4} / \mathrm{HNO}_{3}$ mixture $(1: 7 \mathrm{v} / \mathrm{v}$; Ultrex grade, Baker) and $\mathrm{Pb}$ concentrations in their bodies were measured using a Perkin Elmer 5100 Atomic Absorption Spectrometer equipped with a graphite furnace assembly. Quality of the analysis was controlled by analyzing certified reference material (Dolt 4). Pb recoveries were $85-115 \%$ of the certified value.

Bioaccumulation factors (BAFs) were calculated as the ratio of $\mathrm{Pb}$ concentrations in the collembolans and total $\mathrm{Pb}$ concentrations in the soil.

\subsection{Avoidance test}

The procedure adopted in the avoidance tests was based on International Organization for Standardization (ISO) [21] with some modifications. Cylindrical plastic boxes (diameter, $5 \mathrm{~cm}$; depth, $2 \mathrm{~cm}$ ) were divided into two equal sections by means of a card divider introduced vertically. Ten grams (dry weight equivalent) of a shooting field soil was placed in one of the sections, while the other one was filled with control soil (LF2.2) or a reference soil (R1/R2/R3). Five replicates were tested for each field soil-control/reference combination. After removing the plastic divider, 10 individuals (10-12 days old and without visible signs of damage) were added to each test vessel. To limit water 

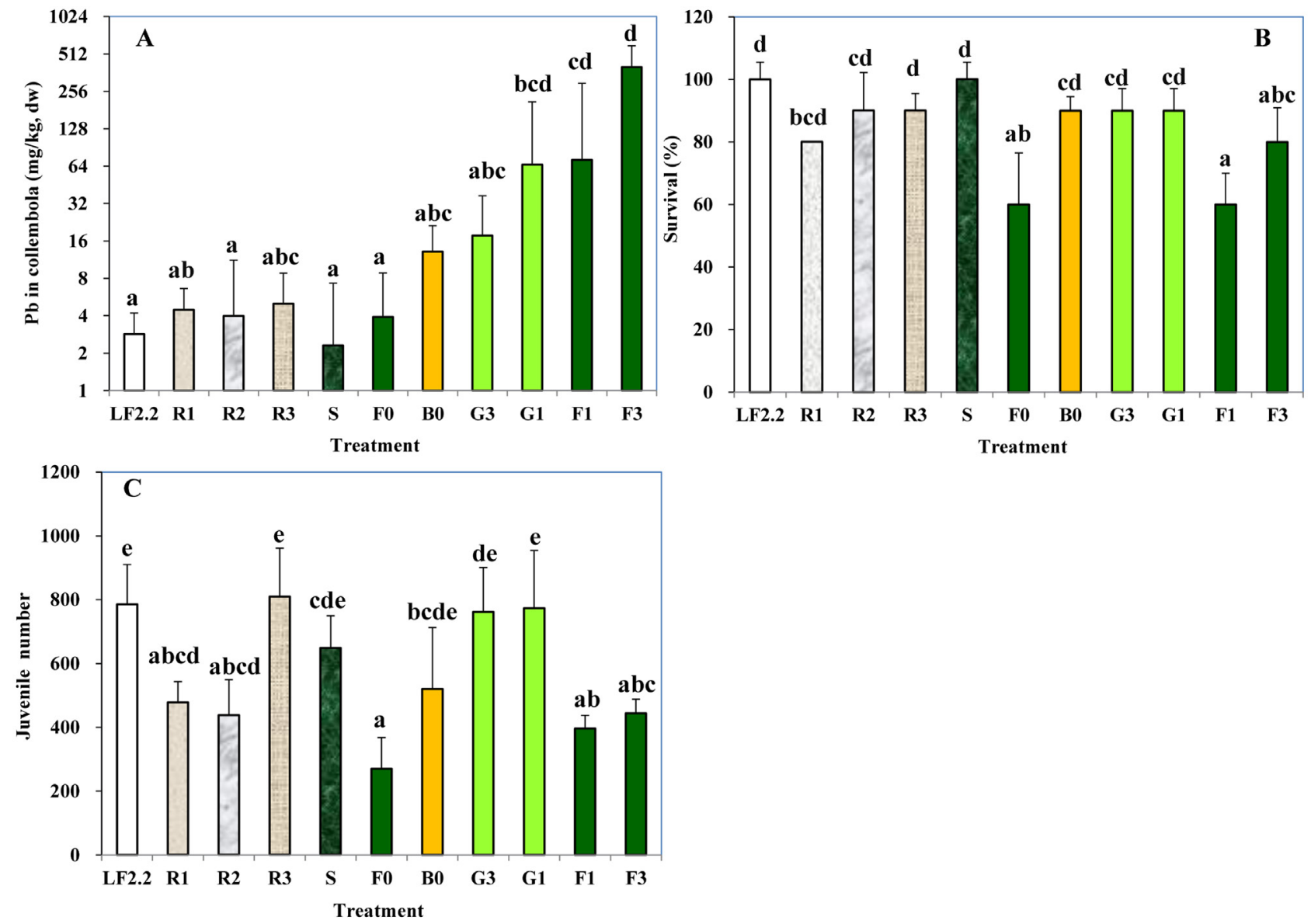

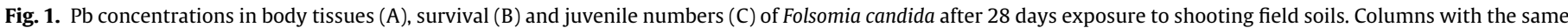
letter indicate no significant differences at $p>0.05$. See [17] for the soil codes and their properties. Error bars show standard deviation $(n=5)$.

evaporation and to prevent collembolans from escaping, the containers were closed with transparent lids. All the containers were incubated at $20 \pm 2{ }^{\circ} \mathrm{C}$ and a $16 / 8 \mathrm{~h} \mathrm{light/dark} \mathrm{photoperiod} \mathrm{for}$ $48 \mathrm{~h}$. At the end of the test period, the two sections of each test container were divided again and emptied into different vessels. These vessels were filled with water and a few drops of blue ink were added. After gently stirring, the individuals floating on the water surface were counted. An additional combination was included containing control or reference soil on both sides of the test container to test for absence of avoidance reaction (dual-control test).

For each replicate the avoidance response was calculated as:

$\mathrm{AR}=\left[\frac{C-T}{N}\right] \times 100$

where, $\mathrm{AR}=$ avoidance response (\%), $C=$ number of collembolans in control or reference soil, $T=$ number of collembolans in shooting field soils, $N=$ total number of collembolans exposed. Avoidance is indicated by a positive attraction or non-response by a negative AR value. The tested soils were considered to have limited or reduced habitat function when $\geq 80 \%$ of the collembolans stayed in the control or reference soil.

\subsection{Data analysis}

All data were examined for both normality and homogeneity of variance (Kolmogorov-Smirnov test). One-way of ANOVA was used to make comparisons. Log transformation had to be applied to obtain normal distribution and homogeneous variances of the data. A multiple comparison test procedure based on Tukey's HSD test was used to further determine differences among means at the 95\% confidence level. Pearson's correlation analysis was conducted to test the significance of the correlations between toxicity and soil physicochemical properties and (bio)available $\mathrm{Pb}$ concentrations $(p<0.05)$. Multiple regressions were carried out to quantitatively analyze the relationship among collembolan bioassay endpoints (survival, reproduction, avoidance response and body residue of $\mathrm{Pb}$ ), level of available $\mathrm{Pb}$, and other soil physicochemical properties. Statistical analyses were conducted using Microsoft Excel and SPSS16.0 software.

\section{Results}

\subsection{Chemical characteristics of shooting field soils}

A full description of the soil properties and metals concentrations has been given by Luo et al. [17]. Here, only a brief summary is provided. The forest soils were most acidic with $\mathrm{pH}_{\mathrm{CaCl}_{2}}$ of 3.2-3.5. The grassland soils had the highest $\mathrm{pH}_{\mathrm{CaCl}_{2}}$ values (6.5-6.8). The bullet plot soil also was acidic with $\mathrm{pH}_{\mathrm{CaCl}_{2}}$ 3.7. Total $\mathrm{Pb}$ concentrations in the shooting field soils ranged from 47 to $2398 \mathrm{mg} / \mathrm{kg} \mathrm{dw}$, and the highest total, $\mathrm{CaCl}_{2}$ - and water-extractable as well as porewater $\mathrm{Pb}$ concentrations were found in the forest soils F1 and F3. All artificial soils (R1-R3) had identical total $\mathrm{Pb}$ concentrations, while they had $\mathrm{CaCl}_{2}$ - and water-extractable $\mathrm{Pb}$ concentrations significantly higher than LF2.2. 


\subsection{Pb uptake in collembolans}

$\mathrm{Pb}$ concentrations in the springtails increased with increasing lead concentrations in the soils (Fig. 1A). The highest $\mathrm{Pb}$ concentrations in the collembolans were found at the highest concentrations of $\mathrm{Pb}$ in $\mathrm{F} 3$ soil. The collembolans exposed to forest soil F0 had the lowest internal $\mathrm{Pb}$ concentration, which was not significantly different from S, LF2.2, B0 and G3 ( $p>0.05)$. Although internal Pb concentrations in the springtails exposed to the three most polluted soils (G1, F1, F3) were not significantly different $(p>0.05)$, they were remarkably higher than those exposed to artificial (R1-R3), soccer field (S) and LF2.2 soils ( $p<0.05)$. The highest BAFs $(0.2)$ were found in grassland soil G1 and forest soil F3, while the lowest BAF (0.07) was observed in grassland soil $\mathrm{G} 3$. Internal $\mathrm{Pb}$ concentrations in $F$. candida were significantly and positively correlated with the different measures of $\mathrm{Pb}$ concentration in the test soils $(p<0.01)$ (Table 1). Simple and stepwise regression analysis showed that internal $\mathrm{Pb}$ concentrations in the collembolans were best explained from total $\mathrm{Pb}$ concentrations in soil (Table 2).

\subsection{Responses of the collembolans}

\subsubsection{Survival}

Survival of $F$. candida in LF2.2, soccer field, bullet plot and grassland soils (Fig. 1B) exceeded the validity criterion of $80 \%$ set by ISO [20]. Survival of the collembolans was somewhat reduced in the forest soils (F0, F1, F3) after 4 weeks of exposure, and was significantly lower than in LF2.2 and soccer field soils $(p<0.05)$. In the other soils, survival was not significantly different from that in LF2.2 or soccer field soils $(p>0.05)$. Survival of $F$. candida was best correlated with $\mathrm{CaCl}_{2}$-extractable $\mathrm{Pb}$ concentrations in the test soils $(p<0.01)$ (Table 1), while also DOC level in porewater seemed to explain survival in the shooting field soils $\left(R^{2}=0.84\right)$ (Table 2). Since mortality was never higher than $40 \%$, no LC50 values for the effect of $\mathrm{Pb}$ on the survival of $F$. candida could be calculated.

\subsubsection{Reproduction}

After 4 weeks exposure, reproduction of $F$. candida in all soils exceeded the minimum of 100 per test container set by ISO for a test to be considered valid [20]. The juvenile numbers of $F$. candida in all forest soils including F0 were significantly lower than in LF2.2 $(p<0.05)$. The grassland soils had significantly higher juvenile numbers than the forest soils $(p<0.05)$ (Fig. 1C). The artificial soils $\mathrm{R} 1$ and $\mathrm{R} 2$, which had high OM content and low $\mathrm{pH}_{\mathrm{CaCl}_{2}}$, respectively, had lower juvenile numbers than R3 and LF2.2 (Fig. 1C). The numbers of juveniles produced were not significantly different among forest, R1 and R2 soils, and also did not differ significantly among grassland soils, bullet plot soil and soccer field soil, R3 and LF2.2.

Juvenile numbers of $F$. candida were significantly and positively correlated with especially soil $\mathrm{pH}$, but negatively with $\mathrm{Pb}$ concentrations $(p<0.01)$ but not total $\mathrm{Pb}$ (Table 1$)$. Juvenile numbers (JN) were best described by $\mathrm{CaCl}_{2}$-extractable $\mathrm{Pb}$ concentrations in the test soils $\left(R^{2}=0.82\right)$ in combination with $\mathrm{Ca}, \mathrm{Cd}, \mathrm{Cu}, \mathrm{Zn}$ contents, $\mathrm{pH}_{\mathrm{H}_{2} \mathrm{O}}$, CEC and DOC levels (Table 2). Since reproduction was never affected by more than $50 \%$ compared to the respective control or reference soil, no EC50 values for the effect of $\mathrm{Pb}$ on the reproduction of $F$. candida were estimated.

\subsubsection{Avoidance test}

The number of dead or missing individuals during the avoidance test was zero in all treatments, fulfilling the validity criterion (less than 10\% missing individuals) of the ISO Guideline 17512-2 [21]. Avoidance responses in all shooting field soils were positive when LF2.2 was used as a reference (Fig. 2). All forest soils had relatively

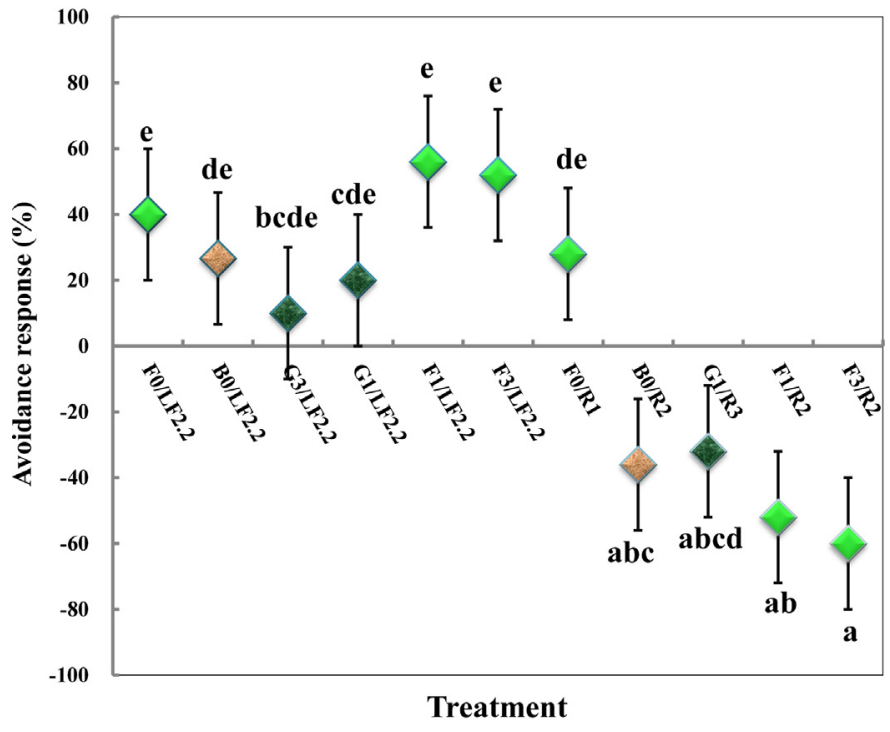

Fig. 2. Avoidance response (\%) of Folsomia candida after 2 days exposure to increasing $\mathrm{Pb}$ concentrations in shooting field soils. See [17] for the soil codes and their properties. Values are mean \pm standard deviation, $n=5$.

high positive avoidance responses, which were not dose-related. The avoidance responses were significantly higher in the forest soils F1 and F3 than in the grassland soils G1 and G3. The grassland soils had relatively low positive avoidance responses, which did not differ from the bullet plot soil (B0). However, avoidance responses in all shooting field soils except for F0 were negative when an artificial soil was used as the reference (Fig. 2). The forest soils F1 and F3 had strong negative avoidance responses when the most acidic R2 soil was used as a reference. Grassland soil G1 had a negative avoidance response with $\mathrm{R} 3$ as the reference, while forest soil $\mathrm{F} 1$ had a positive avoidance response with $\mathrm{R} 1$ as the reference. Unfortunately, the amount of G3 soil available was insufficient to allow for testing the avoidance response compared to the artificial soils. Correlation analysis showed that the avoidance response was only poorly (though significantly) correlated with $\mathrm{CaCl}_{2}$-extractable and porewater with $r$ values $<0.55$ (Table 1 ). $\mathrm{CaCl}_{2}$-extractable $\mathrm{Pb}$ together with total $\mathrm{Cd}, \mathrm{Cu}$ and $\mathrm{Zn}$ concentrations and $\mathrm{pH}$ of the test soils explained only part of the variation in the avoidance response (AR) data $\left(R^{2}=0.58\right)$ (Table 2$)$.

\section{Discussion}

\subsection{Soil properties and availabilities of $\mathrm{Pb}$}

All shooting field soils except F0 had total $\mathrm{Pb}$ concentrations higher than the background levels in Dutch soils $(55-60 \mathrm{mg} / \mathrm{kg} \mathrm{dw}$ ) $[22]$, indicating $\mathrm{Pb}$ contamination in most shooting field soils. The relatively high $\mathrm{Pb}$ concentrations in extracts and pore water of the most polluted soils F1 and F3 [17] may be explained by the low $\mathrm{pH}$ and high OM and DOC levels of these soils. On the other hand, compared to the acid soils F0 and B0, the relatively low concentrations of $\mathrm{CaCl}_{2}$ - and water-extractable and porewater $\mathrm{Pb}$ in the grassland soils $\mathrm{G} 1$ and G3 may be explained from their high pH values. In addition, the high concentrations of $\mathrm{Ca}\left(\right.$ from $\left.\mathrm{CaCO}_{3}\right)$ in soils G1 and G3 may have decreased the solubility of $\mathrm{Pb}$, probably by precipitation as carbonates $[23,24]$. Also $\mathrm{pH}$ may have affected $\mathrm{Pb}$ availability, explaining the great difference in extractable $\mathrm{Pb}$ concentrations between F0 and B0 soils. See our previous paper [17] for a more detailed discussion on factors affecting $\mathrm{Pb}$ availability in soils. 
Table 1

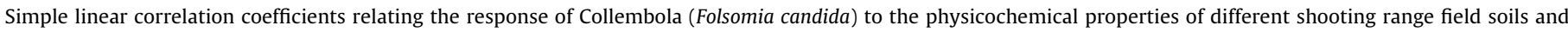
reference soils. See [17] for soil properties and $\mathrm{Pb}$ concentrations and Figs. 1 and 2 for the collembolan responses.

\begin{tabular}{|c|c|c|c|c|}
\hline \multirow{2}{*}{$\begin{array}{l}\text { Soil physico-chemical } \\
\text { properties }\end{array}$} & \multicolumn{4}{|c|}{ Simple linear correlation coefficients $(r)$} \\
\hline & $\begin{array}{l}\text { Pb concentration in } \\
\text { Collembola ( } \mathrm{mg} / \mathrm{kg} \text { dry } \\
\text { body weight) }\end{array}$ & $\begin{array}{l}\text { Number of surviving } \\
\text { Collembola }\end{array}$ & $\begin{array}{l}\text { Number of juvenile } \\
\text { collembolans produced }\end{array}$ & Avoidance response (\%) \\
\hline WHC & 0.20 & -0.15 & -0.25 & 0.16 \\
\hline OM & -0.14 & -0.082 & -0.24 & 0.35 \\
\hline $\mathrm{pH}-\mathrm{H}_{2} \mathrm{O}$ & -0.17 & $0.60^{* *}$ & $0.70^{* *}$ & $-0.47^{* *}$ \\
\hline $\mathrm{pH}-0.01 \mathrm{M} \mathrm{CaCl}_{2}$ & -0.22 & $0.59^{* *}$ & $0.67^{* *}$ & $-0.48^{* *}$ \\
\hline DOC & $-0.30^{*}$ & $-0.29^{*}$ & $-0.50^{* *}$ & 0.30 \\
\hline CEC & $-0.33^{*}$ & $0.41^{* *}$ & $0.32^{*}$ & $-0.45^{*}$ \\
\hline $\mathrm{Ca}$ & $-0.29^{*}$ & $0.55^{* *}$ & $0.56^{* *}$ & $-0.46^{*}$ \\
\hline $\mathrm{Fe}$ & $0.30^{*}$ & -0.13 & 0.052 & -0.086 \\
\hline Clay & $-0.40^{* *}$ & $0.33^{*}$ & 0.090 & -0.19 \\
\hline Silt & $-0.28^{*}$ & 0.20 & 0.056 & -0.24 \\
\hline Sand & $0.37^{* *}$ & $-0.29^{*}$ & -0.080 & 0.21 \\
\hline Pb-Water & $0.72^{* *}$ & $-0.60^{* *}$ & $-0.36^{* *}$ & $0.42^{*}$ \\
\hline $\mathrm{Pb}-0.01 \mathrm{M} \mathrm{CaCl}_{2}$ & $0.61^{* *}$ & $-0.71^{* *}$ & $-0.56^{* *}$ & $0.54^{* *}$ \\
\hline $\mathrm{Pb}$-pore water & $0.70^{* *}$ & $-0.63^{* *}$ & $-0.35^{* *}$ & $0.53^{* *}$ \\
\hline Total Pb & $0.59^{* *}$ & $-0.42^{* *}$ & -0.164 & $0.43^{* *}$ \\
\hline Total Cd & -0.0090 & $0.32^{*}$ & $0.40^{* *}$ & $-0.53^{* *}$ \\
\hline Total Zn & 0.055 & 0.24 & $0.36^{* *}$ & $-0.40^{*}$ \\
\hline Total $\mathrm{Cu}$ & 0.18 & 0.12 & $0.31^{*}$ & $-0.38^{*}$ \\
\hline
\end{tabular}

** Correlation is significant at the 0.01 level (2-tailed)

* Correlation is significant at the 0.05 level (2-tailed).

\section{2. $P b$ uptake in the collembolans}

$\mathrm{Pb}$ concentrations in the collembolans increased linearly with increasing $\mathrm{Pb}$ concentration in the test soils. This was also shown by Bongers et al. [25]. At total soil concentrations of $406-49,200 \mathrm{mg} / \mathrm{kg} \mathrm{dw}$, a fairly constant bioaccumulation factor (BAF) for F. candida of 0.04-0.06 was calculated [14], also supporting the linear increase in body concentrations with increasing exposure level. In our study, the levels of $\mathrm{Pb}$ in $F$. candida appeared to be not significantly different for soils with total $\mathrm{Pb}$ concentrations less than $656 \mathrm{mg} \mathrm{Pb} / \mathrm{kg} \mathrm{dw}$, corresponding with water- or $\mathrm{CaCl}_{2}$-extractable concentrations of 0.47 and $0.18 \mathrm{mg} \mathrm{Pb} / \mathrm{kg} \mathrm{dw}$, respectively or $0.13 \mathrm{mg} \mathrm{Pb} / \mathrm{L}$ in pore water. Since F1 and F3 had similar concentrations of total, water-, $0.01 \mathrm{M} \mathrm{CaCl}_{2}$-extractable and porewater $\mathrm{Pb}$ as well as similar soil properties [17], it is easy to understand that internal $\mathrm{Pb}$ concentrations in $F$. candida exposed to the soils were not significantly different. Low contents of OM, DOC, clay, and silt and high sand content, CEC and Ca concentration may explain the increased $\mathrm{Pb}$ in the body of $F$. candida exposed to G1. Therefore, there was no significant difference of $\mathrm{Pb}$ concentrations in F. candida exposed to F1, F3 and G1. The BAF values in the present study $(0.07-0.2)$ are higher than those reported by Fountain and Hopkin [14], which may be attributed to the much lower $\mathrm{pH}$ and consequent higher $\mathrm{Pb}$ availability in our test soils. The highest correlation coefficients (Table 1) and the highest determination coefficients (Table 2) for $\mathrm{Pb}$ concentrations in the collembolans with water extractable $\mathrm{Pb}$ concentrations in soils suggest that $\mathrm{Pb}$ uptake is mainly from the pore water. Considering that the correlations with other $\mathrm{Pb}$ forms were only slightly lower, ingestion of Pb-polluted soil particles by the collembolans [26-28] may however, also have contributed to exposure. In all forest soils, $\mathrm{pH}$ [17] was below the optimal

Table 2

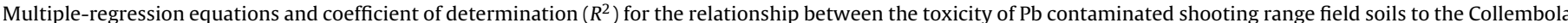
(Folsomia candida) and soil physicochemical properties. See [17] for soil physicochemical properties and Pb concentrations and Figs. 1 and 2 for toxicity data.

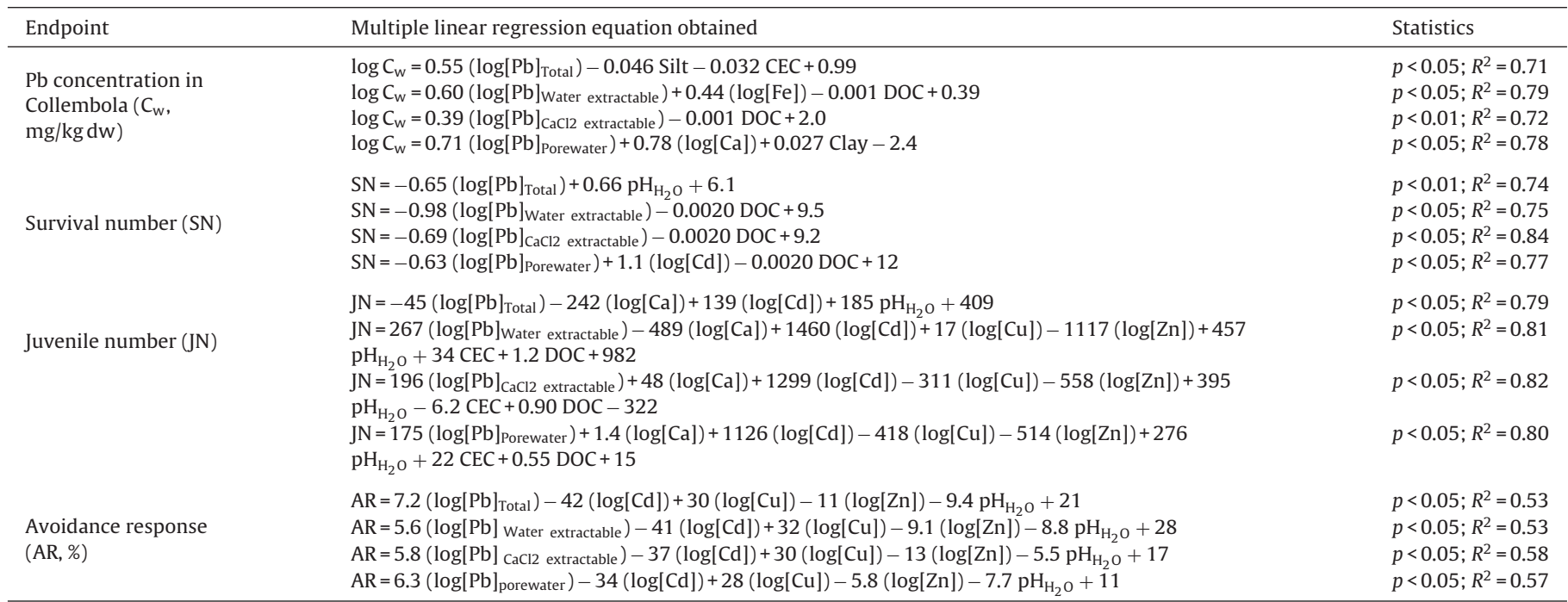


value of 6.0 for $F$. candida [12], which also increased $\mathrm{Pb}$ bioavailability for the collembolans. Therefore, the low pH may amplify the ecological risk caused by bioaccumulation of $\mathrm{Pb}$ in acid soils $[26,29]$.

\subsection{Ecotoxicity of shooting field to collembolans}

\subsubsection{Survival assessment}

Since no dose-related decrease of collembolan survival was seen and no $50 \%$ effect observed, collembolan survival was not sensitive to $\mathrm{Pb}$ contamination. This was also shown by other studies [30-32]. Fountain and Hopkin [14] observed that F. candida feeding on yeast containing up to $49,200 \mathrm{mg} \mathrm{Pb} / \mathrm{kg}$ exhibited no significant changes in survival. Joosse and Verhoef [33] also noticed no significant effect of $\mathrm{Pb}$ on the growth of the collembolan Orchesella cincta. Since total $\mathrm{Pb}$ concentrations in F1 and F3 soils were very close to the LC50 value ( $2900 \mathrm{mg} / \mathrm{kg} \mathrm{dw}$ ) reported for collembolans [25], mortality in these most polluted forest soils might also be related to $\mathrm{Pb}$ contamination.

\subsubsection{Reproduction assessment}

No dose-related decreasing reproduction was seen and 50\% effect was only observed in the acid forest soils F0, F1 and F3 (Fig. 1C). Based on high correlation coefficients (Table 1) and determination coefficients (Table 2), reproduction was better described by $\mathrm{CaCl}_{2}$-extractable $\mathrm{Pb}$ concentrations than by total, waterextractable or porewater $\mathrm{Pb}$ concentrations. Similar results were also observed by other studies [26-28]. Total $\mathrm{Pb}$ concentrations in all our test soils were lower than the LOEC (lowest observed effects concentration) of $2400 \mathrm{mg} \mathrm{Pb} / \mathrm{kg} \mathrm{dw}$ for reproduction of F. candida in a soil with $2 \% \mathrm{OM}, 37.2 \%$ clay and $\mathrm{pH}_{\mathrm{H}_{2} \mathrm{O}}$ 8.2. The total $\mathrm{Pb}$ concentrations in $\mathrm{F} 1$ and $\mathrm{F} 3$ were not only higher than the LOEC of $1200 \mathrm{mg} \mathrm{Pb} / \mathrm{kg} \mathrm{dw}$ for reproduction in a soil with $1.6 \%$ OM, $24.8 \%$ clay and $\mathrm{pH}_{\mathrm{H}_{2} \mathrm{O}} 6.1$, but also significantly higher than the LOEC of $300 \mathrm{mg} \mathrm{Pb} / \mathrm{kg} \mathrm{dw}$ for reproduction in an acidic soil with $16.5 \% \mathrm{OM}, 19.4 \%$ clay and $\mathrm{pH}_{\mathrm{H}_{2} \mathrm{O}} 4.5$ [26]. It was obvious that soil properties, especially $\mathrm{pH}$ and $\mathrm{OM}$ content, influenced $\mathrm{Pb}$ toxicity to F. candida. An EC50 of $2970 \mathrm{mg} / \mathrm{kg} \mathrm{dw}$ was reported for the effect of $\mathrm{Pb}$ on the reproduction of collembolans after 28 days exposure [34], and no offspring was produced by Paronychiurus kimi at $3000 \mathrm{mg} / \mathrm{kg} \mathrm{dw}$ [35]. Lock et al. [36] found that Pb concentrations of $3877 \mathrm{mg} / \mathrm{kg} \mathrm{dw}$ or higher always caused a significant decrease in collembolan reproduction. On the other hand, Menta et al. [30] reported an evidently negative effect on collembolan reproduction by $\mathrm{Pb}$ already at $1000 \mathrm{mg} / \mathrm{kg} \mathrm{dw}$. A Pb concentration of $1312 \mathrm{mg} / \mathrm{kg} \mathrm{dw}$ may cause extinction of populations of $F$. candida [35]. Bongers et al. [25] found an EC50 reproduction for F. candida of $1900 \mathrm{mg} \mathrm{Pb} / \mathrm{kg} \mathrm{dw}$. Nursita et al. [32] were not able to determine an EC50 reproduction for $F$. candida at soil Pb concentrations up to $3000 \mathrm{mg} / \mathrm{kg} \mathrm{dw}$. Therefore, in the present study, it is unlikely that the effect on collembolan reproduction seen in the forest soils was entirely caused by $\mathrm{Pb}$. Although there were significant differences in $\mathrm{Pb}$ concentrations between the forest soils F0, F1 and F3, and between the grassland soils G1 and G3, no significant differences were found in juvenile numbers among the forest soils and between grassland soils. The relatively low juvenile number in the clean soil F0 suggests that the $\mathrm{pH}$ in this soil reached the lower limit of the $\mathrm{pH}$ tolerance range ( $\mathrm{pH}=3.2-7.7)$ for $F$. candida [12]. The effect of the low soil $\mathrm{pH}$ on reproduction was also confirmed by the significantly lower juvenile numbers in soil R2 compared to LF2.2. The significant correlation between juvenile number and $\mathrm{pH}$ also reveals that $\mathrm{pH}$ probably was more important than $\mathrm{Pb}$ in affecting collembolan reproduction. Sandifer and Hopkin [31] reported EC50 $0_{\text {reproduction }}$ values for the effect of $\mathrm{Pb}$ on $F$. candida in soils with different $\mathrm{pH}$ values: $2970 \mathrm{mg} / \mathrm{kg} \mathrm{dw}$ at $\mathrm{pH} 6.0 ; 1360 \mathrm{mg} / \mathrm{kg} \mathrm{dw}$ at $\mathrm{pH} 5.0$ and $3160 \mathrm{mg} / \mathrm{kg} \mathrm{dw}$ at $\mathrm{pH}$ 4.5. Although Sandifer and Hopkin [31] did not find any relationship between effects on reproduction and soil $\mathrm{pH}$, their lowest $\mathrm{pH}$ was still higher than that of the most acid soils in the present study. Therefore, a $\mathrm{pH}$ of 4.5 seems to be a critical threshold, below which the composition of the soil fauna clearly changes. Artificial soil R1, which had high organic content, also had lower juvenile numbers than LF2.2 (Fig. 1C), suggesting that natural soils seem more beneficial for collembolan reproduction than artificial soils.

\subsubsection{Avoidance behavior assessment}

Applying the $80 \%$ avoidance criterion [37], no field soil presented an impaired habitat quality when compared to LF2.2 and the reference soils. The high avoidance in the forest soils F0, F1 and F3 compared to LF2.2 probably was caused by the combination of high $\mathrm{Pb}$ concentrations (particularly the $\mathrm{CaCl}_{2}$-extractable fraction) and low $\mathrm{pH}$. High correlation and determination coefficients between avoidance responses and soil properties (Tables 1 and 2) also indicated that $\mathrm{CaCl}_{2}$-extractable $\mathrm{Pb}$ concentrations seemed to give better predictions of avoidance behavior than other $\mathrm{Pb}$ concentrations and soil properties. Short-term microcosm experiments using compartmented boxes showed that some species dispersed from an acid source to a neutral soil heavily polluted with metals $[38,39]$. The relatively high negative avoidance responses for the forest soils (F1 and F3) with R2 as a reference suggest that artificial soil with both low $\mathrm{pH}\left(\mathrm{pH}_{\mathrm{CaCl}_{2}}=3.8\right)$ and low $\mathrm{Pb}$ concentration $(45 \mathrm{mg} / \mathrm{kg} \mathrm{dw})$ may have higher toxicity than acid forest soils $\left(\mathrm{pH}_{\mathrm{CaCl}_{2}}=3.3-3.5\right)$ with relatively high concentrations of $\mathrm{Pb}$ (2153-2398 $\mathrm{mg} / \mathrm{kg} \mathrm{dw})$. However, avoidance of the acid forest soil F0, which had low Pb concentration ( $47 \mathrm{mg} / \mathrm{kg} \mathrm{dw}$ ), with R1 as reference further suggested that also soil organic matter content was an important factor for determining collembolan avoidance behavior. It therefore is important to highlight a characteristic of this bioassay, already pointed out by other authors $[8,11]$ and the ISO Guideline [21]: soil properties need to be considered when interpreting the results of bioassays on metal-contaminated soils. The influence of soil properties (e.g., pH, organic matter content and texture) upon the avoidance response of collembolans could mask a possible effect of the contaminant. In the present study, correlation and regression analyses indicated that avoidance response was also affected by $\mathrm{Cd}, \mathrm{Cu}, \mathrm{Zn}, \mathrm{Ca}, \mathrm{DOC}$ and CEC. The effects of these soil properties on the performance of the test species therefore should be considered during the assessment of $\mathrm{Pb}$ contaminated soils. It also seems important to select test species that have a broad tolerance range for relevant soil properties, like soil $\mathrm{pH}$.

\section{Conclusion}

Acid forest soils from a shooting field with total Pb concentrations of $2153-2398 \mathrm{mg} / \mathrm{kg} \mathrm{dw}$ and $\mathrm{pH}_{\mathrm{CaCl}_{2}}$ values of 3.5-3.8 had higher toxicity to springtails than grassland soils with total $\mathrm{Pb}$ concentrations of $355-656 \mathrm{mg} / \mathrm{kg} \mathrm{dw}$ and $\mathrm{pH}_{\mathrm{CaCl}_{2}}$ values of $6.5-6.8$. Differences in toxicity were caused by the differences in both $\mathrm{pH}$ and $\mathrm{Pb}$ concentrations between the forest and grassland soils and seemed more affected by low soil $\mathrm{pH}$ than by the high $\mathrm{Pb}$ concentrations. The survival, reproduction and avoidance responses of the collembolans were best described by $0.01 \mathrm{M} \mathrm{CaCl}_{2}$-extractable $\mathrm{Pb}$ concentrations in the test soils. Internal concentrations of $\mathrm{Pb}$ in $F$. candida linearly increased with increasing concentrations of $\mathrm{Pb}$ in the soils. Soil properties significantly affected collembolan survival, reproduction and avoidance response as well as the bioavailability of $\mathrm{Pb}$. Therefore, care must be taken in the selection of reference soils for bioassays with Collembola. A combination of chemical approaches and toxicity tests could help characterizing the risk of $\mathrm{Pb}$-contaminated soils. 


\section{Acknowledgements}

This research was supported by a visitor's grant (number 040.11.222) from The Netherlands Science Foundation (NWO) and by the National Natural Science Foundation of China under Grant No. 41271502.

\section{References}

[1] USEPA, Best management practices for lead at outdoor shooting ranges, in: EPA-902-B-01-001. USEPA, Washington, DC, 2001.

[2] Y. Hashimoto, Field and laboratory assessments on dissolution and fractionation of $\mathrm{Pb}$ from spent and unspent shots in the rhizosphere soil, Chemosphere 93 (2013) 2894-2900.

[3] M. Migliorini, G. Pigino, N. Bianchi, F. Bernini, C. Leonzio, The effects of heavy metal contamination on the soil arthropod community of a shooting range, Environ. Pollut. 129 (2004) 331-340.

[4] W.J.G.M. Peijnenburg, M. Zablotskaja, M.G. Vijver, Monitoring metals in terrestrial environments within a bioavailability framework and a focus on soil extraction, Ecotoxicol. Environ. Saf. 67 (2007) 163-179.

[5] L. Leitgib, J. Kálmán, K. Gruiz, Comparison of bioassays by testing whole soil and their water extract from contaminated sites, Chemosphere 66 (2007) 428-434.

[6] J. Jensen, M.B. Pedersen, Ecological risk assessment of contaminated soil, Rev. Environ. Contam. Toxicol. 186 (2006) 73-105.

[7] C.A.M. Van Gestel, Soil ecotoxicology: state of the art and future directions, Zookeys 176 (2012) 275-296.

[8] M. Udovic, D. Lestan, Eisenia fetida avoidance behavior as a tool for assessing the efficiency of remediation of $\mathrm{Pb}, \mathrm{Zn}$ and $\mathrm{Cd}$ polluted soil, Environ. Pollut. 158 (2010) 2766-2772.

[9] P. Alvarenga, P. Palma, A. de Varennes, A.C. Cunha-Queda, A contribution towards the risk assessment of soils from the São Domingos Mine (Portugal): chemical, microbial and ecotoxicological indicators, Environ. Pollut. 161 (2012) 50-56.

[10] T. Natal-Da-Luz, R. Ribeiro, J.P. Sousa, Avoidance tests with Collembola and earthworms as early screening tools for site-specific assessment of polluted soils, Environ. Toxicol. Chem. 23 (2004) 2188-2193.

[11] M.J.B. Amorim, S. Novais, J. Roembke, A.M.V.M. Soares, Avoidance test with Enchytraeus albidus (Enchytraeidae): effects of different exposure time and soil properties, Environ. Pollut. 155 (2008) 112-116.

[12] S. Jänsch, M. Amorim, J. Römbke, Identification of the ecological requirements of important terrestrial ecotoxicological test species, Environ. Rev. 13 (2005) 51-83.

[13] E.E.V. Chapman, G. Dave, J.D. Murimboh, A review of metal ( $\mathrm{Pb}$ and $\mathrm{Zn}$ ) sensitive and $\mathrm{pH}$ tolerant bioassay organisms for risk screening of metal-contaminated acidic soils, Environ. Pollut. 179 (2013) 326-342.

[14] M.T. Fountain, S.P. Hopkin, Continuous monitoring of Folsomia candida (Insecta: Collembola) in a metal exposure test, Ecotoxicol. Environ. Saf. 48 (2001) 275-286.

[15] K. Lock, C.R. Janssen, Cadmium toxicity for terrestrial invertebrates: taking soil parameters affecting bioavailability into account, Ecotoxicology 10 (2001) 315-322.

[16] C.A.M. Van Gestel, Scientific basis for extrapolating results from soil ecotoxicity tests to field conditions and the use of bioassays, in: N.M. Van Straalen, H. Løkke (Eds.), Ecological Risk Assessment of Contaminants in Soil, Chapman \& Hall, London, 1997, pp. 25-50.

[17] W. Luo, R.A. Verweij, C.A.M. Van Gestel, Determining the bioavailability and toxicity of lead contamination to earthworms requires using a combination of physicochemical and biological methods, Environ. Pollut. 185 (2014) 1-9.

[18] W. Luo, R.A. Verweij, C.A.M. Van Gestel, Contribution of soil properties of shooting fields to lead biovailability and toxicity to Enchytraeus crypticus, Soil Biol. Biochem. 76 (2014) 235-241.
[19] Organization for Economic Cooperation and Development (OECD), Guidelines for the Testing of Chemicals No. 207. Earthworm Acute Toxicity, in: Organization for Economic Cooperation and Development, Paris, 1984.

[20] International Organization for Standardization (ISO), Soil quality - inhibition of reproduction of collembola (Folsomia candida) by soil pollutants, in: ISO 11267. International Standardization Organization, Geneva, Switzerland, 1999.

[21] International Organization for Standardization (ISO), Soil quality - avoidance test for testing the quality of soils and effects of chemicals on behavior - part 1 : test with collembola (Folsomia candida), in: ISO 17512-1. International Organization for Standardization, Geneva, Switzerland, 2008.

[22] J. Vegter, Soil protection in the Netherlands, in: W. Salomons, U. Förstner, P. Mader (Eds.), Heavy Metals-Problems and Solutions, Springer-Verlag, Berlin, 1995, pp. 79-100.

[23] B.J. Alloway, I. Thornton, G.A. Smart, J.C. Sherlock, M.J. Quinn, Metal availability, Sci. Total Environ. 75 (1988) 41-69.

[24] F. Garrido, V. Illera, M.T. García-González, Effect of the addition of gypsum- and lime-rich industrial by-products on $\mathrm{Cd}, \mathrm{Cu}$ and $\mathrm{Pb}$ availability and leachability in metal-spiked acid soils, Appl. Geochem. 20 (2005) 397-408.

[25] M. Bongers, B. Rusch, C.A.M. Van Gestel, The effect of counterion and percolation on the toxicity of lead for the springtail Folsomia candida in soil, Environ. Toxicol. Chem. 23 (2004) 195-199.

[26] T. Bur, Y. Crouau, A. Bianco, L. Gandois, A. Probst, Toxicity of $\mathrm{Pb}$ and of $\mathrm{Pb} / \mathrm{Cc}$ combination on the springtail Folsomia candida in natural soils: Reproduction, growth and bioaccumulation as indicators, Sci. Total Environ. 414 (2012) $187-197$.

[27] T. Crommentuijn, A. Doornekamp, C.A.M. Van Gestel, Bioavailability and ecological effects of cadmium on Folsomia candida (Willem) as influenced by $\mathrm{pH}$ and organic matter, Appl. Soil Ecol. 5 (1997) 261-271.

[28] X. Domene, J.M. Alcaniz, P. Andres, Ecotoxicological assessment of organic wastes using the soil collembolan Folsomia candida, Appl. Soil Ecol. 35 (2007) 461-472.

[29] L. Gandois, A. Probst, C. Dumat, Modelling trace metal extractability and solubility in French forest soils by using soil properties, Eur. J. Soil Sci. 61 (2010) 271-286.

[30] C. Menta, A. Maggiani, Z. Vattuone, Effects of $\mathrm{Cd}$ and $\mathrm{Pb}$ on the survival and juvenile production of Sinella coeca and Folsomia candida, Eur. J. Soil Biol. 42 (2006) 181-189.

[31] R.D. Sandifer, S.P. Hopkin, Effects of $\mathrm{pH}$ on the toxicity of cadmium, copper, lead and zinc to Folsomia candida Willem, 1902 (Collembola) in a standard laboratory test system, Chemosphere 33 (1996) 2475-2486.

[32] A.I. Nursita, B. Singh, E. Lees, The effects of cadmium, copper, lead, and zinc on the growth and reproduction of Proisotoma minuta Tullberg (Collembola), Ecotoxicol. Environ. Saf. 60 (2005) 306-314.

[33] E.N.G. Joosse, S.C. Verhoef, Lead tolerance in Collembola, Pedobiologia 25 (1983) $11-18$

[34] R.D. Sandifer, S.P. Hopkin, Effects of temperature on the relative toxicities of $\mathrm{Cd}, \mathrm{Cu}, \mathrm{Pb}$, and $\mathrm{Zn}$ to Folsomia candida (Collembola), Ecotoxicol. Environ. Saf. 37 (1997) 125-130.

[35] J. Son, M. Ryoo, J. Jung, K. Cho, Effects of cadmium, mercury and lead on the survival and instantaneous rate of increase of Paronychiurus kimi (Lee) (Collembola), Appl. Soil Ecol. 35 (2007) 404-411

[36] K. Lock, N. Waegeneers, E. Smolders, P. Criel, H. Van Eeckhout, C.R. Janssen, Effect of leaching and aging on the bioavailability of lead to the springtail Folsomia candida, Environ. Toxicol. Chem. 25 (2006) 2006-2010.

[37] K. Hund-Rinke, W. Kordel, Underlying issues in bioaccessibility and bioavailability: experimental methods, Ecotoxicol. Environ. Saf. 56 (2003) 52-62.

[38] M. Chauvat, J.F. Ponge, Colonization of heavy metal-polluted soils by Collembola: preliminary experiments in compartmented boxes, Appl. Soil Ecol. 21 (2002) 91-106.

[39] S. Gillet, J.F. Ponge, Are acid-tolerant Collembola able to colonise metal-polluted soil? Appl. Soil Ecol. 26 (2004) 219-231. 